\title{
ECONOMICS
}

\section{WHAT WILL YOU DO IF I SAY 'I DO'?: THE EFFECT OF THE SEX RATIO ON TIME USE WITHIN TAIWANESE MARRIED COUPLES}

by

Simon Chang

Business School

University of Western Australia

\author{
Rachel Connelly \\ Bowdoin College, USA
}

and

Ping Ma

Central University of Finance and Economics

Beijing China

DISCUSSION PAPER 16.05 


\title{
WHAT WILL YOU DO IF I SAY 'I DO'?: THE EFFECT OF THE SEX RATIO ON TIME USE WITHIN TAIWANESE MARRIED COUPLES
}

\author{
Simon Chang \\ University of Western Australia \\ Perth, WA Australia \\ simon.chang@uwa.edu.au \\ Rachel Connelly \\ Bowdoin College \\ Brunswick, ME USA \\ connelly@bowdoin.edu \\ Ping Ma \\ Central University of Finance and Economics \\ Beijing China \\ mpthere1015@gmail.com
}

\section{DISCUSSION PAPER 16.05}

\begin{abstract}
This paper uses the natural experiment of a large imbalance between men and women of marriageable age in Taiwan in the 1960s to test the hypothesis that higher sex ratios lead to husbands (wives) having a lower (higher) share of couple's time in leisure and higher (lower) share of the couple's total work time (employment, commuting and housework). A large sample of Taiwanese couples' time diaries from 1987, 1990, and 1994 is used. The analysis finds evidence of the predicted effects of the county-level sex ratio on husbands' and wives' share of leisure and total work time. In addition, the age difference between husbands and wives is shown to be positively correlated with heightened county-level sex ratio a result which is also consistent with the theory that marriage market participants' choices are affected by the prevailing sex ratio.
\end{abstract}

Keywords: sex ratios, time use, time diaries, Taiwan, marriage markets, bargaining power JEL codes: J12, J16 


\section{Section 1: Introduction}

The equilibrium marriage market model of Becker $(1973,1981)$ and Grossbard $(1984,1993)$ predicts that a larger share of the gains from marriage will go to women if women are present in the marriage market in smaller numbers than men. Similarly, the cooperative bargaining models of Manser and Brown (1980) and McElroy and Horney (1981) also focus attention on the sex ratio of men to women of marriageable age predicting that the sex ratio will affect the veracity of one's threat to divorce. It has been difficult to test this hypothesized relationship between the local sex ratio and the women's bargaining power within marriage since the distribution of martial assets is difficult to observe. In addition, under normal circumstances there is little variation in sex ratios across time or communities. There is, however, a growing empirical literature using regional/time variations in sex ratios and natural experiments that have created variation in the sex ratio to test the effect of the sex ratio on purported outcomes of women's bargaining power in marriage. ${ }^{1}$

We add to this empirical literature by exploiting a natural experiment to explore the effect of a very large deviation from normal sex ratios on the island of Taiwan on the share of the couple's leisure time enjoyed by the wife and the husband. Having both a large deviation and one that comes from an exogenous source provides us with ideal conditions to observe the effect of uneven sex ratios on the division of the marital surplus. In addition, we argue that the share of the couple’s time spent in work or leisure is a much more direct test of women's bargaining power within the household than the other studies have used.

\footnotetext{
1 Angrist 2002, Amuedo-Dorantes and Grossbard 2007, Hackett 2008 use U.S. data; Edlund et al 2013 and Porter 2014 use mainland Chinese data sources; Fortin 2011, Tsai 2011, Edlund, Liu and Liu 2013 use Taiwanese data; Stopnitzky 2011 uses Indian data.
} 
Using data from the Taiwan Time Use Surveys 1987, 1990, and 1994, we find that the county-level effective sex ratio in Taiwan at the time when young men are 20 years old has a robust negative effect on their share of leisure time and a positive effect on their share of total work (employment hours and housework time) within their marriage. The sex ratios are carefully constructed to include Mainland soldiers as well as native Taiwanese civilians (and soldiers), but are broad-based in terms of ages of men and women included so as to be agnostic about the age of marriage. We argue that these broad-based sex ratios are preferable to those based on narrower age ranges since the age gap between men and women marriage partners is also a choice. In fact, we test the effect of the sex ratio on the age gap of married couples in Taiwan and find a significant positive relationship between the age gap and the sex ratio, providing further evidence the men and women respond to the tight marriage market in ways predicted by the economic marriage model. That age gaps change endogenously as a result of the tight marriage market suggests that narrower sex ratios calculated using fixed age gaps used by many of the papers in this literature are ignoring a potential source of reverse causality. The large changes in the sex ratio as a result of a large migration which are clearly exogenous to the marriage market in the Taiwanese case may be better suited for testing truly exogenous sex ratio effects. $^{2}$

The rest of the paper proceeds as follows: Section 2 reviews the theoretical role sex ratios play in bargaining within marriage and presents hypotheses for the effect of sex ratios on time use within couples based on these theories. Section 3 provides background on the circumstances leading to the large sex ratios changes in Taiwan and a literature review summarizing papers in

\footnotetext{
${ }^{2}$ While the migration from mainland China to Taiwan was clearly exogenous it is possible that after the Mainland Chinese soldiers were freed to married that they migrated across counties within the island partly in response to local sex ratios. We test for this possibility later in the paper by using a two stage IV estimation of the county-level sex ratios.
} 
two literatures, the consequences of sex ratio variation on women's bargaining position and the time use literature on intra-couple allocation of time. Section 4 introduces the data and empirical models. Section 5 reports the empirical results. Section 6 offers a variety of robustness checks of the results. We conclude in section 7.

\section{Section 2: The Role of the Sex Ratio in Economic Models of Marriage}

Gary Becker’s work on the economics of marriage revolutionized the way social scientists look at marriage. In his “Theory of Marriage, Part I” (1973), Becker applied simple supply and demand analysis to describe equilibrium in the marriage market. ${ }^{3}$ Men and women (homogeneous within genders in the first blush model) consider the choice to marry or stay single. If they stay single, they retain all of their single output. If they marry they divide up the joint marital output which is expected to higher than the sum of their single outputs due to gains from marriage. When all men are the same and all women are the same, the percent of the marital output men receive (women receiving the remaining share) depends on the relative number of men to women, that is, the sex ratio. If there are more identical men than identical women, women get a larger share of the joint marital output and men receive just enough to make them indifferent between marrying or not. Even when the assumption of homogeneous men and women is removed, the sex ratio remains a key variable. Once everyone is not the same, the sex ratio is shown to affect the percent of the population who marry as well as the equilibrium marriage share.

Becker's equilibrium model is often contrasted with bargaining models which predict that the gains from marriage will go to the member of the couple with the stronger bargaining position. In the cooperative bargaining models of Manser and Brown (1980) and McElroy and Horney

\footnotetext{
${ }^{3}$ Becker elaborated on this model in his 1981 volume, The Treatise on the Family and Grossbard expanded upon it in Grossbard-Shechtman (1984, 1993).
} 
(1981) power differentials depend on factors that affect the value of one's threat to divorce. If part of the gain from divorce is the potential of an alternative marriage match, then sex ratios should affect men's and women's relative position in the remarriage market. Thus, in terms of the predicted effect of sex ratios on household distribution within marriage, the equilibrium model and the "divorce as a threat point” model yield the same hypothesis. Similarly, in the collective model of household bargaining of Browning et al (1994) and Chiappori et al (2002), often proposed as a compromise between Becker’s equilibrium approach and the bargaining model approach, the sex ratio is one of the "distribution factors" that shifts the household sharing rule toward the relatively scarcer sex. As such, the collective model of household bargaining also predicts that a higher sex ratio will lead to a greater share of the marital assets going to the wife.

\subsection{Sex Ratios' Predicted Effect on Time Use and Age at Marriage}

The relative time use of a husband and wife within a marriage is a particularly good window through which to observe power relationships within a couple. Time use patterns are something that are negotiated by the couple, yet they have a strong habit component so that agreements negotiated at the time of marriage will still be evident years later (Schober 2013). Time use hypotheses consistent with all three economic models reviewed above are that the member of the couple with more power in the marriage market will spend more of his or her time in inherently pleasant pursuits and less of his or her time in inherently unpleasant pursuits. A number of previous studies have looked at time use within a couple and power although in those studies power is proxied by relative wage rates rather than local sex ratios. Housework time has been the focus of most of the studies in this area because of a sense that housework falls into the 
category of time that is inherently unpleasant. ${ }^{4}$ However, new data on time specific contemporaneous subject well-being shows that employment is viewed as equally unpleasant as housework by both men and women (Connelly and Kimmel 2014). For this and the following reason, housework share is not our preferred margin on which to measure women's power within their marriage in Taiwan in the 1980s and 90s.

In Taiwan during the period captured by the married couples around 1990, gender roles were quite segregated and married women's labor force participation rates were low. In the analytic sample used for the empirical analysis below, 49 percent of the women were employed during the previous week, but that number would have been even lower when many of the marriages captured in the time use data were begun. In 1978, the earliest year with available data in Taiwan, the women's labor force participation rate was 38 percent. $^{5}$ Because of the low rate of women's labor force participation and the connected high rate of full-time homemaking, we do not expect higher bargaining power in the marriage market would necessarily lead to a lower share of housework time. In fact, both Angrist (2002) and Tsai (2011) show that high sex ratios lead to lower rates of labor force participation which may result in a higher share of housework. Thus, instead of the share of housework time, we focus on the share of "total work" which has been argued by Burda, Hamermesh, and Weil (2013) to be the margin of couples’ equity concerns.

Burda, Hamermesh and Weil (2013) hypothesize that married men and women calibrate their total work load with each other leading to what the authors call "isowork", that is equal work. They show that in a host of different countries married men and women in the same education

\footnotetext{
${ }^{4}$ Stratton (2012) showed there are a range of feelings about time spent doing housework tasks as there are with every time use.

[5 Based on authors’ own calculation using Taiwan Manpower Survey in 1978.
} 
groups have very similar levels of total work, but that the level of work differs substantially across countries and within countries across education categories. Connelly and Kimmel (2014) question the empirical equality of total work using time diary surveys for men and women in the U.S. separated by household type (married with children, young married without children, older married without children, single without children and single with children). Within each category they show that women have greater hours of total work than men. Still they find that the gaps in total work are substantially smaller than the gaps in housework. Thus, we predict that men and women in Taiwan considering marriage during the study period were more likely to be negotiating over total work than housework specifically. Those men who married during the period of heightened sex ratios are predicted to do a larger share of the total work of the couple than men marrying in periods with normal sex ratios. In the same vein we hypothesize that heightened sex ratios at the time of life-course decision making will lead to men having a lower share of the couples' leisure. Maintenance time, that is, time needed to maintain oneself, sleeping, personal grooming and eating, is predicted to be unaffected by the effective sex ratio since that time use involves very little choice.

While sex ratios of a given population can be thought of as exogenous to the participants in a given marriage market, participants can theoretically make some changes in order to be more attractive in any given marriage market. In some cases, marriage-age men or women could relocate for the purpose on improving their marriage chances. For example, high school seniors in the U.S. might consider the sex ratios at the various colleges as one of the criteria they use to choose among colleges. It is harder to think about a more settled population experiencing substantial migration solely to move to a more advantageous marriage market. Easier to imagine is men in a tight marriage market trying to improve their rankings among the group of men 
currently in the market for wives. Chang and Zhang (2015) provide strong evidence of Taiwanese men increasing their level of entrepreneurship in light of the high sex ratios of the 1960s marriage market. Edlund et al (2013) considers the effect of sex ratios on education choices of young men and women in China for a similar reason and finds evidence that high sex ratios leading to higher levels of male premarital investments in education.

In this paper we consider an alternative strategy men may use to distinguish themselves among their competitors, that is, by courting younger women. Porter (2014) argues that men in Mainland China have a preference for women only a few years younger than themselves. She uses national statistics on age differentials among married couples in China as evidence of revealed preference for a small age gap. However, when marriage markets are tight for men (sex ratios are high) women have more bargaining power and may choose older, more accomplished, men. (Bergstrom and Bagnoli 1993, Bergstrom and Schoeni 1996, Zhang 1995) Thus, we hypothesize that the age difference within marriage will be positively related to the prevailing sex ratio. This becomes an additional testable hypothesis using the couples-based time use survey already employed to analyze the shares of couples' leisure and total work time. ${ }^{6}$

While we expect that men can affect their competitiveness in the marriage model somewhat via premarital investments, all men in the market have similar incentives. This problem is well known in the animal world where natural selection on traits that increase competitiveness in mating leads to a general "raising of the bar" phenomenon, which ultimately results in peacock tails too heavy to carry or walrus tusks too large to use effectively (Frank 2011). In terms of the

\footnotetext{
${ }^{6}$ Porter (2014) tested the hypothesis that age differences within marriage would be positively related to the sex ratio using Mainland Chinese data, but did not find significant effects. On the other hand, she finds that the age of marriage for men does increase with the sex ratio and the age of marriage for women is unaffected by the sex ratio which provides indirect support for a widening age gap.
} 
analysis of time use shares within couples, this general equilibrium view of the sex ratios leads to the prediction that sex ratio effects cannot be completely escaped. We hypothesize that though college educated and non-college educated men (and women) compete for mates in largely separate marriage markets, the effect of general population-wide sex ratios will have significant effects on women's bargaining power in both markets.

\section{Section 3: Background and Literature Review}

\subsection{Historical Background of Sex Ratios in Taiwan}

After the Chinese Nationalist Party (also known as Kuomintang) was defeated by the Chinese Communist Party in the civil war in Mainland China during 1945-1949, a great number of Kuomintang soldiers and civilians sympathizers retreated to the island of Taiwan around 1949. Various studies suggest that the number of civil war immigrants ranges between 0.6 and 1.25 million, while Taiwan's local population was then only 6 million (Barclay 1954; Jacoby 1967; Ho 1978; Chen and Yeh 1982; Liu 1986; Lin 2002). Among the immigrants, the soldiers who were mostly single males in their early twenties were estimated to have exceeded half a million. It is thus not surprising that the composition of the immigrants was highly male-biased. Francis (2011) suggests that among the immigrants, men outnumbered women by a factor of 4 to 1 , leading to a significant and sudden rise in the sex ratio in Taiwan.

To further complicate the relevant sex ratio in the marriage market, Kuomintang soldiers were not allowed to marry in the 1950s. (Lin 2002) In 1952, the marriage ban was formally written into a law called the Military Marriage Ordinance (MMO). ${ }^{7}$ The MMO forbade most active military personnel from getting married, except for military officers and technician sergeants. In August 1959, the ban was relaxed for most soldiers, except for male soldiers

\footnotetext{
${ }^{7}$ The ban was de facto effective even before the law was enacted.
} 
younger than 25 , female soldiers younger than 20 , and all soldiers who had served fewer than three years. ${ }^{8}$ This relaxation essentially made the MMO nonbinding for most immigrant soldiers from Mainland China, who either were already older than 25 or had served more than three years by 1959 . This meant that they could finally get married roughly 10 years after their arrival in Taiwan.

In the mid-1950s, the Kuomintang began to conscript young Taiwanese men to replace aging immigrant soldiers. In principle, conscripted Taiwanese men were also subject to the marriage ban. However, unlike their immigrant counterparts, Taiwanese soldiers generally served only for two or three years and remained socially connected to their communities outside the military. As such we hypothesize that the ban was less binding on them.

The entrance of the Mainland Chinese men into the marriage market produced large changes in the sex ratio. Figure 1 shows the imputed prime-age (age 15-49) marriage eligible sex ratio (the solid line) rose dramatically twice. The first rise occurred in 1949 when the Kuomingtang and its followers retreated to Taiwan; the second even larger increase happened in 1960 when the marriage ban for soldiers was lifted. Overall, the sex ratio rose from close to one man per woman before 1940 to nearly 1.2 men per woman in 1960 and stayed at that plateau until 1970 as the immigrants gradually aged out of the prime age category. The line of connected dots indicates the percentage of women aged 15 or more who are married in Taiwan. As shown, there is a clear co-movement between the prime-age sex ratio and women's marriage rate, as predicted by the economic models of marriage.

The sex ratios also differ by region within Taiwan based mostly on where the military were located. Figure 2 plots the sex ratios by the Mainland Chinese (Panel A) and native Taiwanese

\footnotetext{
${ }^{8}$ In 1974, the MMO was further relaxed to include only soldiers currently involved in combat and students in military academies. It was completely repealed in 2005.
} 
(Panel B) for the 21 counties and cities in Taiwan in 1956 (black bars) and 1966 (white bars) based on the decennial population census, which included the whole population of both civilians and soldiers. Panel A shows that the group of Mainland Chinese immigrants was highly malebiased. All the sex ratios are substantially above one. Some of them are even as high as two. In addition, there is also time variation in their sex ratios, suggesting that some of the Mainland Chinese may have migrated across county borders within Taiwan. ${ }^{9}$ This observation leads to a concern that the county-level sex ratios could be endogenous if, for example, a single Mainland Chinese man finding it difficult to find a wife in county A where the sex ratio is high decides to move to county B where the sex ratio is lower. However, since the Mainland Chinese men competed with the native Taiwanese men for the native Taiwanese women, if migration were caused by the sex ratio, then we would expect single native Taiwanese men would also have migrated for marriage purposes. Panel B does not support this hypothesis. On the contrary, the sex ratios among the native Taiwanese were quite balanced and stable across counties and time. The graphical evidence suggests that the migration of the Mainland Chinese men is unlikely to have been motivated by marriage competition. Despite this, we also employ an instrumental variable approach as a robustness test to mitigate concerns about the potential for marriage market correlated internal migration.

\section{2: Literature Review on Sex Ratios and Decision Making in Marriage}

This paper contributes to two literatures that have thus far remained fairly separate: the literature on sex ratio effects on women's bargaining position within marriage and the literature on intra- couple time use and bargaining power. Both literatures are large. Here we highlight only those contributions to each literature that are particularly relevant to our analysis.

\footnotetext{
${ }^{9}$ An alternative hypothesis is that the age distribution of soldiers may have been different at different army bases.
} 


\section{2.a: Empirical Effects of the Sex Ratio on Proxies of Women's Empowerment Within Marriage}

We have organized this section by the proxy variable used to represent women's empowerment within marriage or her share of the marital surplus. The reader will observe that many dependent variables have been considered including labor force participation rates, the quality of the marital relationship, marriage, divorce and fertility rates, consumption levels of husbands, wives and children. How these proxies are affected by the sex ratio depends on what is valued by men and women. Thus, each choice of dependent variable requires additional assumptions such as less labor force participation is preferred to more, women prefer to spend more money on children's needs than men, women prefer to have more children than men etc. One problem is that these preferences may differ from one culture to another.

Labor Force Participation: Angrist (2002) uses differential sex ratios within immigrant communities in U.S. cities to consider the effect of sex ratios on the labor force participation of second generation immigrants in the U.S. He finds that women who live in ethnic communities with high sex ratios are less likely to be in the labor market. Amuedo-Dorantes and Grossbard (2007) use U.S. Current Population Survey data to measure cohort sex ratios and their effect on women's labor force participation. They also find that higher cohort sex ratios lower women's labor force participation. Using Taiwanese data, Tsai (2011) uses the sex ratio among the Taiwanese immigrants as an instrumental variable for the sex ratio of the post-war cohort. She too finds that a higher sex ratio lowers women's labor force participation.

Relationship Quality: Harknett (2008) uses the Fragile Family data to consider the effect of sex ratios on various measures of relationship quality. A higher sex ratio is correlated with fathers being more likely to visit the mother in the hospital after the birth, higher scores on mutual supportiveness measures and lower scores on within couple conflict measures. 
Housework Share: Edlund et al (2013) use the Chinese Health and Nutrition Survey data to estimate the effect of province-level sex ratios on Mainland Chinese husbands' housework time. They find that a 10 percent increase in the sex ratio reduces the gender gap in household chores by 13 percent.

Individual Consumption: Porter (2014) uses the Chinese Health and Nutrition Survey with a more complicated algorithm for estimating the appropriate sex ratio for each man or woman in the sample than Edlund et al (2013). Dependent variables include the alcohol and tobacco consumption of men, boys' and girls' heights and weights, and husbands' and wives' age at marriage. She finds robust effects of the sex ratio on boys' weight and on husbands alcohol and tobacco consumption. She argues that mothers with more bargaining power use their increased power to increase the well-being of their sons whom they expect to care for them in their old age.

Francis (2011) exploiting the same natural experiment used in this paper of the large exogenous change in the sex ratio in Taiwan, considers the effect of the unequal sex ratios on the ratio of bride price to dowry and a set of children outcomes such as the fraction of female children and children's educational attainment. He finds that higher sex ratios increase the bride price to dowry and reduce the sex ratio of children.

Fertility Rates: Francis (2011) also considers the effect of Taiwanese sex ratios on number of children ever born. Higher sex ratios are correlated with lower fertility rates. Edlund, Liu and Liu (2013) also uses Taiwanese data, but from a more recent era than Francis (2011) or this paper. Their analysis considers the effect of foreign brides on the bargaining position of Taiwanese women. Foreign brides lower the effective sex ratio and are thus expected to lower women's bargaining power in the marriage market. They find that an increase in the number of foreign brides increases fertility rates. 
Marriage and Divorce Rates: Edlund, Liu and Liu (2013) also analyzed the effect of effect of the sex ratio on divorce rates. They found that an increase in the number of foreign brides in Taiwan reduces divorce rates. Earlier, Angrist (2002) found that women who live in ethnic communities in the U.S. with high sex ratios are more likely to be married. Harknett (2008) also working with U.S. data finds that fathers in locations with higher sex ratios were more likely to marry the mother of their child. Tsai (2011) using Taiwanese data finds that a higher sex ratio increases women's marriage rate. This relationship also can be seen clearly in Figure 2 above.

\section{2.b: Previous Time Diary Studies Exploring Bargaining Power within the Household}

As discussed above, most of the early work on time use and women's empowerment focused on housework and used relative income or wages as the measure of power within the household. For example, Hersch and Stratton (1994) use data from the Panel Study of Income Dynamics in the U.S. to test the effect of husband and wife's relative income on housework time and on the share of husband's housework time of the total housework time of the couple. They find that husbands in two-earner couples with a higher share of labor income do less housework controlling for hours worked.

Connelly and Kimmel (2009a) use predicted relative wages of husbands compared to wives as their measure of relative power within the household. However, wages themselves may be the result of hours decisions made in the past and have also been shown to be affected by number of hours spent on housework. To address these endogeneity concerns, Connelly and Kimmel (2009a) use predicted wages rather than actual wages. Using data from the American Time Use Survey they consider housework time, leisure time, and child caregiving time separately for fathers and mothers with children under age 13. They find no significant effect of relative wages 
on any of these three aggregate time use categories. ${ }^{10}$ In Connelly and Kimmel (2009b) they add predicted hours of the spouse's time in the same time use categories to their empirical specification and again test of the effect of relative wages on the time use of mothers and fathers. Again, no significant effect of relative wages on time use is found.

Gupta and Stratton (2010) argue that housework may not be the right place to look for power differentials between spouses and that relative wages may not be the right measure of power. Housework, they argue, has the disadvantage that it produces public goods which women may have higher preference for than men, while leisure is more intimately connected to individual utility gains. Instead they find more hypothesis-consistent results using relative education measures as the power proxy and leisure time as the marginal minutes being adjusted. They find that women with higher levels of education compared to their spouses enjoy more leisure time especially on non-work days.

Relative education, annual income share, or relative wages are each seeking to capture the financial bargaining power of the individual man and woman who have already married. But the economic marriage models outlined above make a case for considering marriage market sources of bargaining power that are common to all men and women contemplating marriage at a particular time. The sex ratio at the time men and women are contemplating marriage is predicted to exert an independent effect on bargaining power. Using the Taiwanese data which captures very large variation in sex ratios we test the effect of sex ratio on three broad time-use categories described in more detail below: maintenance time, total work time, and leisure time. The analysis of leisure time provides a direct test of the Gupta and Stratton (2010) hypothesis,

${ }^{10}$ Other studies that used relative wages as a predictor of time use include Freidberg and Webb 2007, Kan 2008 and Chiappori et al 2002. Studies that used the share of annual earnings include: Geist 2005, Fuwa 2004 and Bittman et al 2003. 
while using total work time addresses some of the concerns of the same authors with housework time as a specific category.

\section{Section 4: Data and Empirical Specification}

Our data on time use come from the Taiwan Time Use Surveys of 1987, 1990, and 1994. These are nationally representative surveys collected by the Directorate-General of Budget, Accounting and Statistics, Executive Yuan of Taiwan. We restrict the sample to couples with husbands as the household head aged between 25 and 64. The sample includes 8,312 couples from 1987, 5,599 couples from 1990 and 4,223 couples from 1994. The three survey years are merged into a single analytic sample with dummies in the multivariate estimation to denote which sample year source of the data. Those sample year dummies are never statistically significant.

$$
S_{i j t}=\beta_{0}+\beta_{1} R_{j t}+\boldsymbol{B} \boldsymbol{X}_{i j t}+C_{\mathrm{j}}+\varepsilon_{i j t}
$$

Equation 1 is used to test the hypothesis that increased sex ratio, the number of men per woman, in county $\mathrm{j}$ when the husband who was born in year t was age $20, \mathrm{R}_{\mathrm{jt}}$, increases (deceases) the share of total work done by the husband (wife) and decreases (increases) the share of leisure time enjoyed by the husband (wife). The dependent variables, $\mathrm{S}_{\mathrm{ijt}}$, are the share of the husband's or the wife's time of the couple’s total time spent in three mutually exclusive and collectively exhaustive aggregate time categories: maintenance time, total work time and leisure time. For example, the formula for the share of leisure time enjoyed by the wife is $S_{\mathrm{Lw}}=t_{\mathrm{Lw}} /\left(\mathrm{t}_{\mathrm{Lw}}\right.$ $+t_{L h}$ ), that is, the time the wife spends in leisure activities, $t_{L w}$, divided by the total time the couple spends on leisure activities, $\mathrm{t}_{\mathrm{Lw}}+\mathrm{t}_{\mathrm{Lh}}$. Similarly, the share of leisure time enjoyed by the husband is $S_{L h}=t_{L h} /\left(t_{L w}+t_{L h}\right)$. Maintenance time is mostly sleep, but also includes grooming, eating and drinking. It is the time that each individual needs to maintain the functionality of 
daily living. It is not time that can be transferred nor do we expect there to be much decision making related to it. Total work time is the sum of employment time (including commuting time) and housework time. We combine employment and housework time because these activities are mostly done for the outcome rather than the process. The time used is transferable, that is, someone else can do them for us allowing us to enjoy the outcome without spending the time. Employment time and home production time are also similar to one another in how we feel while doing them. Connelly and Kimmel (2015, p. 21) show that employment time has as high a level of unpleasantness rating as many household tasks. Similarly, in the happiness only ranking for U.S. fathers and mothers, other home production, housework, and employment ranked $11^{\text {th }}$, $12^{\text {th }}$ and $13^{\text {th }}$ out of 13 activities by women and $12^{\text {th }}, 13^{\text {th }}$, and $11^{\text {th }}$ by men for the same 13 activities. (Connelly and Kimmel 2014)

Leisure time is the residual after having accounted for maintenance time and total work time. Most leisure activities are non-transferable consumption activities, such as taking a walk or reading a book. Some may have an investment component like reading a book that will contribute to one's labor market competitiveness and others may have an utility producing outcome, like a nice garden or a set of new curtains, but mostly they are activities engaged in because we enjoying spending the time in that way. Connelly and Kimmel (2015) show that the average leisure activity is considered unpleasant much less often than the average housework or employment activity.

The key independent variable, $R_{j t}$, the effective sex ratio at county level when the husband was 20 years of age, is partly imputed. In Taiwan, the official population data are collected through a civilian household registration system. However, prior to 1969, the number of active military personnel was treated as a state secret and excluded from the civilian registration system, unless 
they got married (Lin 2002). In November 1968, this exclusion was changed by an executive order that required all military personnel to be registered in the civilian system. This means that until 1969, the immigrant soldiers did not show up in official population data. Consequently, the raw sex ratio calculated from official population data prior to 1969 is underestimated. To correct the bias of the raw sex ratio before 1969, we impute the effective sex ratios that better reflect the intensity of competition in the marriage market. In particular, we adopt the imputation method proposed by Chang (2013).We exclude the immigrant soldiers in the calculation of the effective sex ratios before 1960 because they were effectively subject to the MMO. However, the Taiwanese soldiers are still included in the effective sex ratio, because of their short duration of service and strong social ties, even though they were also subject to the MMO.

We evaluate the county-level effective sex ratio when the husband was age 20 presumably just beginning to contemplate marriage. We choose this early age to allow for the effects of sex ratios on premarital investments. The sex ratio at 20 is predicted to affect both premarital investments and ultimately the bargaining position of men in the marriage market. In the sample, husbands reached age 20 during 1943-1989. As a robustness check, we also use age 23. The effective sex ratio is defined as the number of men per woman among the cohort of marriageable age 15-49. To allow for age gap between husband and wife, we also use men of age 20-49 versus women of age 15-44 as a robustness check. Due to lack of data on residence history, we use current residence as proxy for residence at age 20 or 23.

While the data is well suited to considering couples' time use shares as it includes time diaries for both the husband and wife in the same couple, the data is limited in terms of additional covariates. We do not have information on number of children at home or the age of marriage. We do have information on current age, employment status, and educational attainment which 
we include in broad categories of no schooling, primary, junior high school, senior high school and college. More specifically, $\boldsymbol{X}_{i j t}$ in equation (1) is a vector of individual attributes including age, age squared, education dummies and a dummy indicating if the respondent was working last week, a dummy indicating a non-rainy day and a dummy indicating weekend when the time diary was collected, two dummies indicating the year that the survey was collected, and 10-year birth cohort dummies. We also included a set of county-level fixed effects, $C_{\mathrm{j}}$, to control for county-specific factors, such as the presence of a military base, industrial structures, or resource endowment. $\varepsilon_{i j t}$ is the assumed iid error term.

$$
D_{i j t}=\beta_{0}+\beta_{1} R_{j t}+\mathbf{B} \mathbf{Z}_{i j t}+\mathrm{C}_{j}+\varepsilon_{i j t}
$$

Equation 2 is the specification for the age difference equation. $D_{i j t}$ is the age difference between the husband and the wife for husband $i$ in county $j$ who were born in year $t . \boldsymbol{Z}_{i j t}$ includes husband's age, age squared, and in one specification education levels of the husband. The other terms are defined the same as in equation (1).

For both the share equations and the age difference equation, OLS is used since both dependent variables are continuous variables. For statistical inference, we use robust standard errors clustered by counties.

\section{Section 5: Empirical Results}

\section{1: Descriptive Statistics}

Table 1 summarizes the variables separately for the husbands and the wives. Overall, husbands have slightly more total work time and leisure time than the wives, while the wives spend slightly more time on maintenance than husbands do. The average husband is older than the average wife; the average age is 44.55 for the husband and 40.7 for the wife. The average age gap within a marriage couple is 3.78 years. The mating competition among men seems 
severe, as the average county sex ratio when the husband was 20 years old across the full sample is about 1.12, meaning 112 men would have been competing for only 100 women. About 96 percent of the husbands reports that they worked in the last week, while it is only 49 percent for the wives were employed. As for the time diaries, about 60 percent of them were collected on weekends and 66 percent on a non-rainy day.

\section{2: OLS Results on Share Equations of Husbands and Wives}

The results in Panel A of Table 2 show that the county-level sex ratio when the husband was age 20 has a significantly positive effect on the husband's time share in total work time and a significantly negative effect on his leisure time. Specifically, if the sex ratio increases by one standard deviation (0.1), the husbands’ share in total work time will increase by 0.0058 $(0.058 * 0.1)$, which is about $1 \%$ of average total time share. Thus, the quantitative effect is not large, but it is consistent with marriage surplus hypothesis in terms of the direction. It is not surprising that the effect is quantitatively small. Much of time use is proscribed by the structure of the labor market, the structure of the educational system for children's time, social norms about child-raising and cultural norms about gender roles.

We repeated the estimation using the wives' shares and her own demographic characteristics but the sex ratio when her husband was age 20. Panel B of Table 2 shows the wives' results. The sex ratio of one's husband at age 20 is shown to have a significantly negative effect on the wife’s total work time share and a positive but imprecisely measured effect on her leisure time share. The magnitudes of the effects on the wife's share of total time and leisure are quite similar in absolute value to those of the husbands as they should be given that the dependent variables are the shares of total couple time engaged in by each member of the couple. However, no constraints were placed on these coefficients and the estimating equations differ in the $\mathbf{X}$ 's as the 
husband's equation uses the husband's age and education, while the wife's equation uses her age and education.

Finally, we note that there are no significant effects on the sex ratio on maintenance time for either husbands or wives a result which is consistent with our hypothesis since we expect very little decision making in maintenance time and no transferring of maintenance time from husband to wife and vice versa.

\section{3: OLS Results on Share Equations by Education}

The relationship between education and the marriage market is complicated. On the one hand, higher education can be thought of as premarital investment engaged in (in part) to increase one's earning potential and in so doing to make one a preferred marriage partner. If this were the only effect of education on marriage markets, we would expect that those men with higher levels of education would be able to escape to some degree the effect of the sex ratio on their bargaining position. On the other hand, if men with higher education want to marry women with higher education or at least to marry women with higher ability even if this higher ability is not "blessed" with education, then their marriage market is narrower and a high sex ratio may be even more binding on them, leading to the prediction that higher educated men will have less bargaining power.

Yet a third predicted effect of education on marriage works through the relationship between education and hours worked. The data show that less educated husbands usually take jobs that require working longer hours than their college-educated counterparts. In our sample, the average market work time for the less educated husbands is 435 minutes per day, while it is 372 minutes for the college-educated husbands. Although these are ex post marriage market work times, it is reasonable to suspect that the former group would have worked longer hours than the 
latter group even before they were married given the difference in the institutional structures of their labor markets. Provided that there is a physical upper limit to working hours for average workers, shorter market work time for college-educated men would allow more room for a sex ratio effect. Thus, we would expect the college-educated husbands to experience a larger sex ratio effect on time use shares based on this third effect.

Table 3 presents the results of OLS estimated coefficient of the county-level sex ratio on the three aggregated time use shares for couples with college-educated husbands and those with less educated husbands. Two important conclusions emerge from Table 3. The first is that the sex ratio effect are still positive for total work time and negative for leisure time for husbands in both education categories. For wives the results are again reversed in sign from the husbands, with significant negative effects on total work time and positive effects on leisure time. The second insight from Table 3 is that the magnitudes of the sex ratio effects are substantially larger for the couples with college-educated husbands. The biggest effects are observed for college-educated husbands whose coefficient on total work time share is more than three times larger than it was in general population (Table 2). Similar large effects are found for college-educated husbands' leisure share. Correspondingly, their wives' share of total work time is also substantially lower than in the general population and their share of leisure time is positively and significantly affected by the relevant sex ratio. These larger effects for the college-educated group provide evidence that education alone does not allow one to escape the effect of a tight marriage market. If anything, positive assortative mating and the relationship between education and work hours exacerbate the situation. ${ }^{11}$

\footnotetext{
${ }^{11}$ Higher education may have helped their chances of marrying. Here our sample is limited to already married couples.
} 


\section{4: The Effect of the Sex Ration of Age Difference of Husbands and Wives}

We argued above that age difference between husband and wife could be expected to be a function of the tightness of the marriage market. In Table 4 we present results of the estimation of equation 2. Column 1 differs from column 2 only in the inclusion of the husband's educational dummies in column 2 . The results show that higher sex ratios when the husband was 20 do lead to a larger spousal age difference. Specifically, if the sex ratio increases by one standard deviation (0.1), the spousal age difference is predicted to increase by 0.3764 (3.764*0.1), which is about 10 percent of average age difference.

Controlling for the level of the husband's education as is done in column 2 we find that those husbands with no education (the omitted category) or primary education only have the smallest spousal age gap, while those with education higher than primary school all have approximately three quarters of a year larger of an age gap. Comparing columns 1 and 2 we find that controlling for the husband's education level leaves the county-level sex ratio effect virtually unchanged.

That age differences between spouses are affected by county-level sex ratios is independent evidence of the importance of general marriage market conditions on individuals' choices in marriage. It is also evidence that individuals respond to competition in the marriage market by changing their set of potential partners. Using narrowly defined sex ratios, especially those with fixed age gaps between men and women, will miss some of the effect of sex ratio imbalance on peoples’ choices.

\section{Section 6: Robustness Checks}

So far we have used the sex ratio for a wide cohort aged 15-49 when the husband was 20 years old. When hundreds of thousands of Mainland Chinese male immigrants flooded into the 
marriage market after the marriage ban was removed in 1959, many were already in their 30s or 40s. These men had to look for younger wives as most women their own age were already married. The age gap of partners in a first marriage exceeded more than five years by 1970 . Table 4 above showed that the age gap grew during this period of the most intense shortage of marriageable women. As such, one may question whether the ratio of men to women in the same age range, specifically $15-49$, accurately reflects the actual supply and demand situation in the Taiwanese marriage market. As a robustness check, we repeated the regressions in Table 2 with an alternative sex ratio - the county-level ratio of men aged 20-49 to women 15-44 years old. As shown in Panels A and B of Table 5, the basic results still hold. The coefficients on the sex ratio for the share of total work time and leisure time are significant for the husbands with opposite signs. The signs are reversed for the wives and the magnitudes of the coefficients are quite similar between husbands and wives. For wives again only the effect of sex ratios on total work share is significant.

In addition, in Table 2 we used the county-level sex ratio when the husband was 20 years old as the marriage market determining sex ratio. Perhaps 20 is a bit young for making marital market relevant decisions. In Panels $\mathrm{C}$ and $\mathrm{D}$ of Table 5, we present the results using sex ratios (symmetric in terms of the men's and women's age range as before) when the husband was 23. Again the results are quite similar to those presented in Table 2.

Finally, we consider the possibility that while migration to the island was exogenous to the marriage market, internal migration may have been motivated by sex ratios. If men in counties with skewed sex ratios could easily marry women in counties with more normal sex ratios, then the operational sex ratio at the county level would not be a good measure of the actual local marriage market tightness. Such a measurement error could cloud a precise estimation of the true 
impact. Moreover, as explained above, the county-level sex ratios used are partly imputed. The imputation itself could generate other measurement errors.

To mitigate these endogeneity concerns, we apply an instrument variable approach, originally adopted by Chang and Zhang (2015), as a robustness check. We know that the degree of sex ratio imbalance was largely associated with the number of Chinese men from the Mainland. However, we argue that the initial spatial distribution of Mainland Chinese men was exogenous in a sense that it was mainly determined by political or military concerns as most of the Mainland Chinese men were either soldiers or civil servants who were assigned to take most of the military or public posts in Taiwan under Chiang Kai-Shek’s ruling (Lin 2002). We thus use the number of Mainland Chinese at the county level in the 1956 Population Census to measure the initial spatial distribution. Furthermore, since this is the distribution before the marriage ban was lifted in 1959, it is less likely to be influenced by the marriage-driven migration.

The initial distribution may have caused differential impacts on different birth cohorts who entered the marriage market in different years. We thus interact the number of the county Mainland Chinese men (in log form) with the 10-year cohort dummy indicating birth cohorts of 1940-1949. The choice of the cohort dummy is guided by the timing of the lifting of the marriage ban and the assumption of age 20 as the age when men begin to think about marriage markets.

We report the first-stage estimation results in Table 6 . The dependent variable is the county sex ratio when the husband was 20 years old. In both regressions for husbands and wives, the interaction of the instrument with the 1940-1949 cohort dummy is positive and statistically significant. This suggests that compared to the other cohorts, the initial distribution of Mainland Chinese men has a larger and positive effect on the sex ratio for the 1940-1949 cohorts. 
Table 7 shows the two-stage least square regression (2SLS) estimations. The coefficient for the sex ratio variable is again significant in the share of total work time for husbands and wives. The coefficient is negative for husband's leisure share and positive for wives though it is only significant for the wives' leisure share. The magnitudes are somewhat larger in absolute value than the OLS estimates in Table 2. The endogeneity tests have rather large p-values for all but the wives' share of total work, suggesting that the OLS and 2SLS estimates are not statistically different except for this one regression. This lack of significance implies that the aforementioned endogeneity concerns probably do not cause much bias provided that the instruments are valid. Overall, the 2SLS estimates show that the sex ratio effects are fairly robust to these endogeneity concerns.

\section{Section 7: Conclusion}

The sex ratio in the local marriage market is a key variable in the Becker (1973) model and continues to play a similar role in alternative economic models of the marriage market offered by Manser and Brown (1980) and McElroy and Horney (1981), and by Browning et al (1994) and Chiappori et al (2002). Sex ratios offer empirical researchers a source of exogenous variation with which to test the basic economic hypothesis that individuals respond in predictable ways to changes in the underlying market conditions surrounding marriage.

Since Becker’s (1973) model was first published, scores of empirical papers have been written analyzing the effect of variation in the sex ratio on marriage-related outcomes. The set of marriage-related outcomes is quite large, from marriage rates, age at marriage and age gaps in marriage, to women's labor market behavior, to proxies for relative bargaining power within the household, such as women's outcomes, joint decision making on household consumption, and children's outcomes. We have argued that the share of couple's leisure time and couple's total 
work time are more direct lens through which to observe the effect of sex ratios on the sharing of the gains from marriage or bargaining power within marriage.

We test the hypotheses that the share of the couple's leisure time enjoyed by the husband (wife) will decrease (increase) and his (her) share of the couple's total work time (employment time, commuting time and home production time) will increase (decrease) when sex ratios are high. Using time diary data from Taiwan collected in the 1987, 1990, and 1994 we find strong support of the overarching hypothesis that sex ratios matter. Taiwanese men and women, during the time period represented by the marriages of a sample of couples with husbands between ages 25 and 64 in 1987-1994, experienced vastly varying sex ratios with highs well above average because of male-centric immigration in 1949 and a subsequent military marriage ban until 1959. The empirical results show that higher sex ratios increase husbands' share of total work time and reduce their share of leisure time. Similarly, higher sex ratios are shown to lower wives' share of total work time and increase their share of leisure time though the effect for women is often measured less precisely. In addition, the age gap between husbands and wives increased with a higher county-level sex ratio. College-educated men in Taiwan are found to have experienced an even larger sex ratio effect and do a substantially higher share of the total work within the couple than less educated men when faced with the same county-level sex ratio, providing evidence that the sex ratio is more binding in thinner markets or for populations not working near the physical maximum of work hours.

Finally, these sex ratio effects on shares of couple's time were shown to be robust to alternative ways of measuring the county-level sex ratio. IV estimates were also offered which would be appropriate if the county-level fixed effects used in the other models were not sufficient to control for the potential endogeneity of county-level sex ratios with the marriage 
market. The spatial distribution of the sex ratio of native Taiwanese men in Figure 2 suggests that endogeneity should not be a large concern. The IV results confirm this observation with the insignificance of three out of four endogeneity tests and the qualitative similarity of the results in terms of the signs of the sex ratio effect from the IV model to those from the OLS estimation.

It is humbling for us as humans to recognize that not everything is under our control. Just as birth cohort effects have been shown repeatedly to matter in one's life course, it appears that so too do marriage cohorts. While we can try to change our competitiveness within the marriage marketplace, all participants have equal incentives to do so and thus bidding wars ensue. Perhaps, in the end, this explains why we have created notions of fairness, to reduce the competition and even the playing field so that one's fortune will be less variable than the sex ratios may be. 


\section{REFERENCES}

Amuedo-Dorantes, C., \& Grossbard, S. (2007). Cohort-level Sex Ratio Effects on Women’s Labor Force Participation. Review of Economics of the Household, 5(3), 249-278.

Angrist, J. (2002). How Do Sex Ratios Affect Marriage and Labor Markets? Evidence from America's Second Generation. Quarterly Journal of Economics, 117, 997-1038.

Barclay, G. W. (1954). Colonial Development and Population in Taiwan. Princeton, NJ: Princeton University Press.

Becker, G. (1973). A Theory of Marriage: Part I. Journal of Political Economy, 81(4), 813-846.

Becker, G. (1981). A Treatise on the Family. Cambridge, MA: Harvard University Press.

Bergstrom, T. \& Bagnoli, M. (1993). Courtship as a Waiting Game. Journal of Political Economy, 101(1), 185-202.

Bergstrom, T. \& Schoeni, R. (1996). Income Prospects and Age-at-Marriage. Journal of Population Economics, 9(2), 115-130.

Bittman, M., England, P., Sayer, L., Folbre, N. \& Matherson, G. (2003). When Does Gender Trump Money? Bargaining and Time in Household Work. American Journal of Sociology, 109(1), 186-214.

Burda, M., Hamermesh, D., \& Weil, P. (2013). Total Work and Gender: Facts and Possible Explanations. Journal of Population Economics, 26(1), 239-261.

Chang, S. (2013). Civil War, Marriage Ban, and Sex Ratio: Impute the Prime-Age Sex Ratio in Post-War Taiwan Using Censored Data. Asian Population Studies, 9(1), 1-18.

Chang, S. \& Zhang, X. (2015). Mating Competition and Entrepreneurship: Evidence from a Natural Experiment in Taiwan. Journal of Economic Behavior and Organization, 116, 292-309. 
Chen, K.-J., \& Yeh, T.-F. (1982). Changes of Age Composition in Taiwan, 1905-1979. National Taiwan University Journal of Population Studies, 6, 99-114. (In Chinese)

Chiappori, P.-A., Fortin, B., \& Lacroix, G. (2002). Marriage Market, Divorce Legislation, and Household Labor Supply. Journal of Political Economy, 110(1), 37-72.

Choo, E. \& Siow, A. (2006). Who Marries Whom and Why. Journal of Political Economy, 114(1), 175-201.

Connelly, R. \& Kimmel, J. (2009a). Spousal Economic Factors in ATUS Parents’ Time Choices. Social Indicator Research, 93, 147-152.

Connelly, R. \& Kimmel, J. (2009b). Spousal Influences on Parents’ Non-Market Time Choices. Review of Economics of the Household, 7(4), 361-394.

Connelly, R. \& Kimmel, J. (2015). If You Are Happy and You Know It: How Do We Really Feel about Child Caregiving? Feminist Economics, 21(1), 1-34.

Connelly, R. \& Kimmel, J. (2014). Unpaid Time Use by Gender and Family Structure. In E. Redmount (Ed.), The Economics of the Family: How the Household Affects Markets and Economic Growth (pp. 67-114). Santa Barbara, CA: ABC-CLIO.

Edlund, L., Liu, E., \& Liu, J.-T. (2013). Beggar-Thy-Women: Domestic Responses to Foreign Bride Competition, the Case of Taiwan. Unpublished paper.

Edlund, L., Li, H., Yi, J. \& Zhang, J. (2013). Sex Ratios and Crime: Evidence from China. Review of Economics and Statistics, 95(5), 1520-1534.

Francis, A. (2011). Sex Ratios and the Red Dragon: Using the Chinese Communist Revolution to Export the Effect of the Sex Ratio on Women and Children in Taiwan. Journal of Population Economics, 24, 813-837. 
Freidberg, L. \& Webb, A. (2005). The Chore Wars: Household Bargaining and Leisure Time. Unpublished paper.

Fuwa, M. (2004). Macro-level Gender Inequality and the Division of Household Labor in 22 Countries. American Sociological Review, 69(6), 751-767.

Geist, C. (2005). The Welfare State and the Home: Regime Differences in the Domestic Division of Labour. European Sociological Review, 21(1), 23-41.

Frank, R. (2011). The Darwin Economy: Liberty, Competition, and the Common Good. Princeton, NJ: Princeton University Press.

Grossbard-Shechtman, S. (1984). A Theory of Allocation of Time in Markets for Labour and Marriage. Economic Journal, 94, 863-82.

Grossbard-Shechtman, S. (1993). On the Economics of Marriage. Boulder CO: Westview Press. Gupta, N. \& Stratton, L. (2010). Examining the Impact of Alternative Power Measures on Individual Time Use in American and Danish Couple Households. Review of Economics of the Household, 8(3), 325-343.

Harknett, K. (2008). Mate Availability and Unmarried Parent Relationships. Demography, 45(3), $555-571$.

Hersch, J. \& Stratton, L. (1994). Housework, Wages, and the Division of Housework Time for Employed Spouses. The American Economic Review, Papers and Proceedings, 84(2), $120-125$.

Ho, S. (1978). Economic Development of Taiwan: 1860-1970. New Haven, CT: Yale University Press.

Jacoby, N. (1967). U.S. Aid to Taiwan: A Study of Foreign Aid, Self-Help, and Development. New York: F. A. Praeger. 
Kan, M. Y. (2008). Does Gender Trump Money? Housework Hours of Husbands and Wives in Britain. Work, Employment, Society, 22(1), 45-66.

Kovács, B. \& Bálint, L. (2014). Explaining Sleep Time - Hungarian Evidences. Electronic International Journal of Time Use Research, dx.doi.org/10.13085/eIJTUR.11.1.43-56.

Lin, S.-W. (2002). The Transition of Demographic Sexual Structure in Taiwan: 1905-2000. National Chengchi University Journal of Sociology, 33 (2002), 91-131. (In Chinese)

Liu, K.-C. (1986). Population Growth and Economic Development in Taiwan. Taipei, Taiwan: Linking Books. (In Chinese)

Manser, M. \& Brown, M. (1980). Marriage and Household Decision-Making: A Bargaining Analysis. International Economic Review, 21(1), 31-44.

McElroy, M., \& Horney, M. J. (1981). Nash-Bargaining and Household Decisions: Towards a Generalization of the Theory of Demand. International Economic Review, 22(2), 333349.

Porter, M. (2014). How Do Sex Ratios in China Influence Marriage Decisions and IntraHousehold Resource Allocation? Online Review of Economics of the Household, http://link.springer.com /article/10.1007/s11150-014-9262-9/fulltext.html.

Stopnitzky, Yaniv. (2012). The Bargaining Power of Missing Women: Evidence from a Sanitation Campaign in India. Unpublished paper available at SSRN 2031273.

Stratton, L. (2012). The Role of Preferences and Opportunity Costs in Determining the Time Allocated to Housework. American Economic Review, 102(3), 606-11.

Strober, P. (2013). Maternal Labor Market Return and Domestic Work after Childbirth in Britain and Germany. Community, Work and Family, 16(3), 307-326. 
Tsai, W.-J. (2011). Imbalanced Sex Ratios, Marriage Opportunities and Labor Market Outcomes: A Natural Experiment Based on Chinese Migration in the late 1940s. Taiwan Economic Review, 39, 511-540. (In Chinese)

Zhang, J. (1995). Do Men with Higher Wages Marry Earlier or Later? Economics Letters, 49(2), 193-196. 
Figure 1: Prime-Age Sex Ratio and Women Marriage Rate

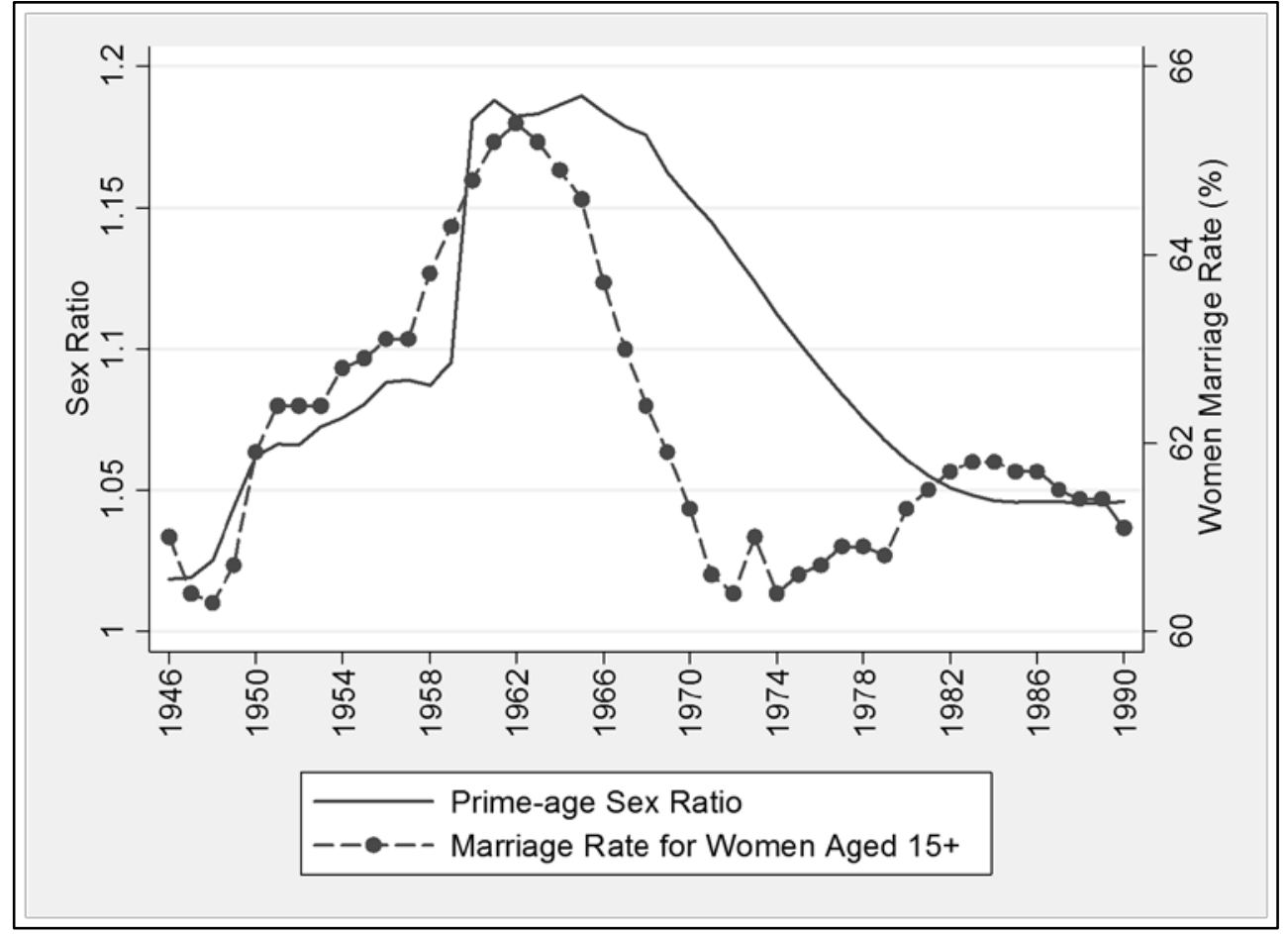

Notes: Prime-age sex ratio is defined as the number of men per women for ages 15-49; marriage rate is the percentage of married women among all women who are at least 15 years old.

Sources: Prime-age sex ratio is derived from the authors' own calculation; women marriage rates are from various Taiwan Demographic Fact Books published by the Ministry of Interior, Taiwan. 
Figure 2: County Sex Ratios for Mainland Chinese and Native Taiwanese in 1956 and 1966 Panel A: Mainland Chinese

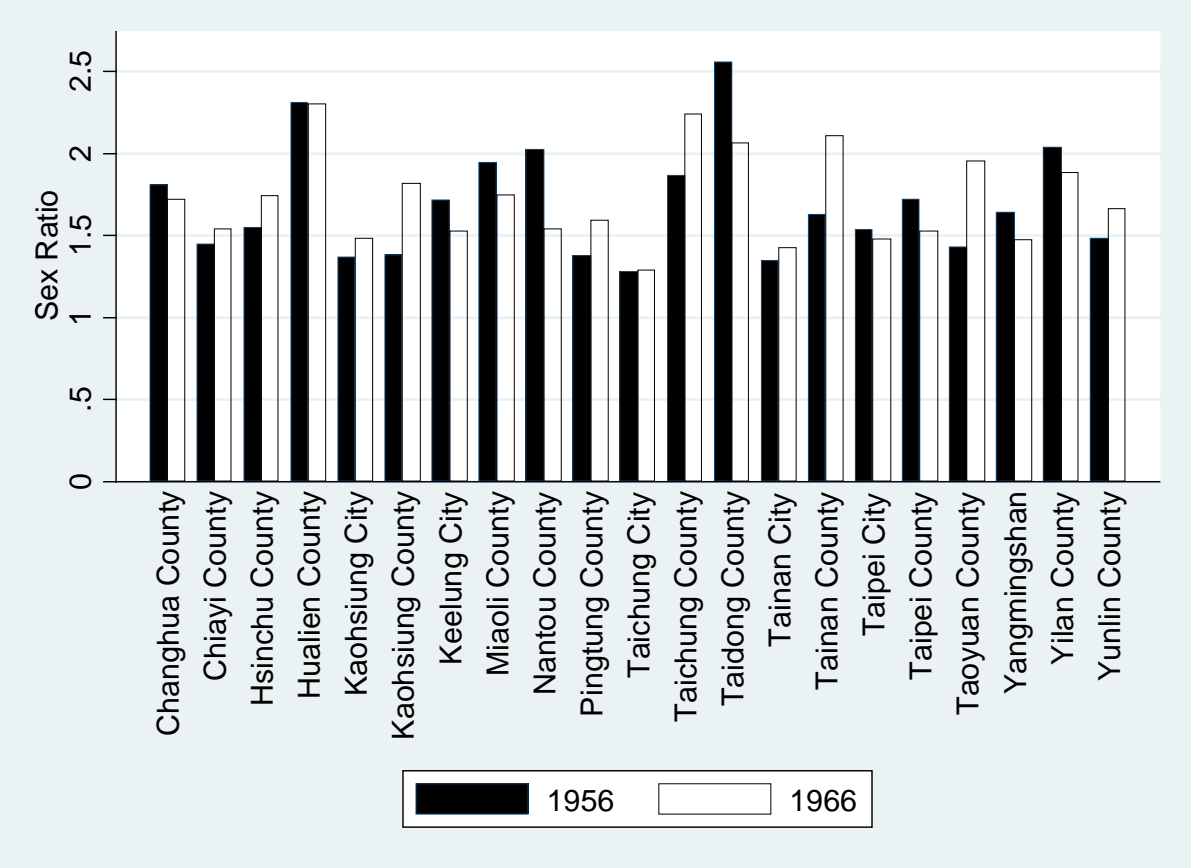

Panel B: Native Taiwanese

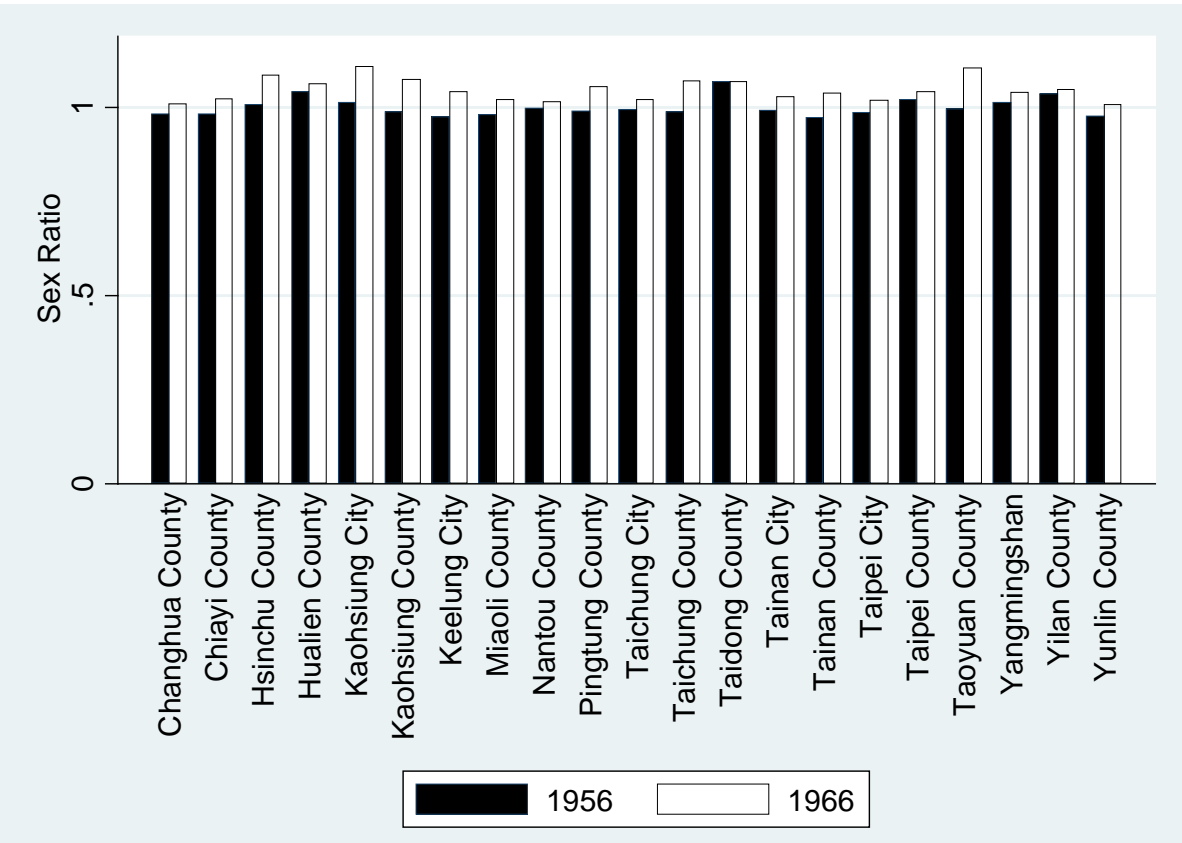

Notes: County sex ratios include both the civilian and institutionalized populations.

Sources: 1956 and 1966 Taiwan Population Census, DirectorateGeneral of Budget, Accounting and Statistics, Executive Yuan, R.O.C. (Taiwan) 


\begin{tabular}{|c|c|c|c|c|}
\hline \multicolumn{5}{|c|}{ Table 1. Summary Statistics } \\
\hline & \multicolumn{2}{|c|}{$\begin{array}{c}\text { (1) } \\
\text { Husband }\end{array}$} & \multicolumn{2}{|c|}{$\begin{array}{l}(2) \\
\text { Wife }\end{array}$} \\
\hline & Mean & SD & Mean & SD \\
\hline Maintenance time share & 0.499 & 0.033 & 0.501 & 0.033 \\
\hline Total work time share & 0.501 & 0.143 & 0.499 & 0.143 \\
\hline Leisure time share & 0.507 & 0.159 & 0.493 & 0.159 \\
\hline Age & 44.51 & 10.11 & 40.73 & 9.990 \\
\hline Age difference $b / w$ husband and wife & 3.78 & 4.48 & 3.78 & 4.48 \\
\hline \multicolumn{5}{|l|}{ Education } \\
\hline (1) No schooling & 0.065 & 0.247 & 0.177 & 0.382 \\
\hline (2) Primary & 0.449 & 0.497 & 0.470 & 0.499 \\
\hline (3) Junior & 0.163 & 0.370 & 0.134 & 0.341 \\
\hline (4) Senior & 0.192 & 0.394 & 0.158 & 0.365 \\
\hline (5) College \& above & 0.130 & 0.337 & 0.060 & 0.238 \\
\hline Sex ratio when husband was 20 & 1.118 & 0.101 & 1.118 & 0.101 \\
\hline Worked last week & 0.961 & 0.194 & 0.492 & 0.500 \\
\hline Diary taken at weekends & 0.603 & 0.489 & 0.604 & 0.489 \\
\hline Diary taken on a non-rainy day & 0.662 & 0.473 & 0.661 & 0.473 \\
\hline \multicolumn{5}{|l|}{ Survey year } \\
\hline 1987 & 0.458 & 0.498 & 0.458 & 0.498 \\
\hline 1990 & 0.309 & 0.462 & 0.309 & 0.462 \\
\hline 1994 & 0.233 & 0.423 & 0.233 & 0.423 \\
\hline Observations & 18,134 & & 18,134 & \\
\hline \multicolumn{5}{|c|}{$\begin{array}{l}\text { Notes: Time shares are ratios of either husband's or wife's time to the sum of the } \\
\text { couple time in each time category. Sex ratios are evaluated at county level. } \\
\text { Education difference is the difference in education categories. } \\
\text { Data source: Taiwan Time Use Survey 1987, 1990, 1994, Directorate-General of } \\
\text { Budget, Accounting and Statistics, Executive Yuan, R.O.C. We restrict the sample } \\
\text { to couples with husband as the household head aged between } 25 \text { and 64. The } \\
\text { analysis sample consists of } 8,312 \text { couples in 1987, 5,599 couples in 1990, and } \\
4,223 \text { couples in } 1994 \text {. }\end{array}$} \\
\hline
\end{tabular}




\section{Table 2. OLS Estimates of the Sex Ratio Effect on Time Shares}

(1) (2)

Maintenance time Total work time
(3)

Leisure time

Sex ratio

Panel A: Share of Husband's Time

\begin{tabular}{ccc}
\hline 0.0009 & $0.0578^{* * *}$ & $-0.0388 * * *$ \\
$(0.21)$ & $(5.69)$ & $(-3.76)$ \\
\hline \multicolumn{3}{c}{ Panel B: Share of Wife's Time } \\
\hline-0.0029 & $-0.0430 * * *$ & 0.0179 \\
$(-0.84)$ & $(-3.42)$ & $(1.34)$
\end{tabular}

Sex ratio $(-0.84)$ $(-3.42)$

Notes: Dependent variables are shares of either husband's or wife's time to the sum of the couple's time in each time category. Sex ratios are evaluated at county level when the husband was 20 years old. All regressions additionally control for husband's or wife's age and age squared, a full set of husband's or wife's education dummies, a dummy indicating if the respondent was working last week, if the weather was a nonrainy day and the day was a weekend when the time diary was taken, two dummy variables indicating year 1990 and 1994 and a full set of county dummies and 10-year birth cohort dummies. $t$ statistics in parentheses are clustered at county.*, ** and *** indicates significant at $10 \%, 5 \%$ and $1 \%$ respectively. 
Table 3. Sex Ratio Effect on Time Shares by Husband's Education

(1)

(2)

(3)

Maintenance time Total work time

Leisure time

Couples with Less Educated Husbands

Sex ratio

Panel A: Share of Husband's Time

\begin{tabular}{ccc}
\hline 0.0028 & $0.0383^{* * *}$ & $-0.0227^{*}$ \\
$(0.71)$ & $(3.04)$ & $(-1.96)$ \\
\hline \multicolumn{3}{c}{ Panel B: Share of Wife’s Time } \\
\hline-0.0040 & $-0.0311^{* *}$ & 0.0111 \\
$(-1.17)$ & $(-2.28)$ & $(0.77)$ \\
\hline
\end{tabular}

Sex ratio

Couples with College Educated Husbands

Sex ratio Panel C: Share of Husband's Time

\begin{tabular}{ccc}
\hline-0.0089 & $0.1788^{* * *}$ & $-0.1300^{* * *}$ \\
$(-0.84)$ & $(5.35)$ & $(-3.00)$ \\
\hline \multicolumn{3}{c}{ Panel D: Share of Wife's Time } \\
\hline 0.0027 & $-0.1216^{* * *}$ & $0.0712^{* *}$ \\
$(0.34)$ & $(-4.61)$ & $(2.11)$
\end{tabular}

Sex ratio (0.34)

Notes: Panel A and B use the subsample for husbands whose education is below college and the sample size is 15,770. Panel C and D use the subsample for husbands whose education is college or above and the sample size is 2,364. Sex ratios are evaluated at county level when the husband was 20 years old. All regressions additionally control for husband's or wife's age and age squared, a dummy indicating if the respondent was working last week, if the weather was a non-rainy day and the day was a weekend when the time diary was taken, two dummy variables indicating year 1990 and 1994 and a full set of county dummies and 10-year birth cohort dummies. $t$ statistics in parentheses are clustered at county. ${ }^{*}, * *$ and $* * *$ indicates significant at $10 \%, 5 \%$ and $1 \%$ respectively. 
Table 4. OLS Estimates of Sex Ratio Effect on Spousal Age Gap

\begin{tabular}{|c|c|c|}
\hline \multirow[b]{2}{*}{ Sex ratio } & (1) & (2) \\
\hline & $\begin{array}{c}3.764 * * * \\
(4.37)\end{array}$ & $\begin{array}{c}3.677 * * * \\
(4.08)\end{array}$ \\
\hline \multicolumn{3}{|c|}{ Husband's education } \\
\hline \multicolumn{2}{|l|}{ Primary } & $\begin{array}{l}-0.084 \\
(-0.40)\end{array}$ \\
\hline \multicolumn{2}{|l|}{ Junior } & $\begin{array}{c}0.749 * * * \\
(2.90)\end{array}$ \\
\hline \multicolumn{2}{|l|}{ Senior } & $\begin{array}{c}0.815^{* * * *} \\
(2.93)\end{array}$ \\
\hline College & & $\begin{array}{c}0.679 * * \\
(4.39)\end{array}$ \\
\hline \multicolumn{3}{|c|}{$\begin{array}{l}\text { Notes: The dependent variable is age difference between the husband and the } \\
\text { wife. Sex ratios are evaluated at county level when the husband was } 20 \text { years } \\
\text { old. The reference group for husband's education in column (2) is no } \\
\text { education. } t \text { statistics in parentheses are clustered at county. Both regressions } \\
\text { additionally control for husband's age, age squared, two dummy variables } \\
\text { indicating year } 1990 \text { and } 1994 \text {, a full set of county dummies and } 10 \text {-year birth } \\
\text { cohort dummies. *, ** and *** indicates significant at } 10 \%, 5 \% \text { and } 1 \% \\
\text { respectively. }\end{array}$} \\
\hline
\end{tabular}




\section{Table 5. Robustness Check Using Alternative County-Level Sex Ratios}

\begin{tabular}{|c|c|c|c|}
\hline & $\begin{array}{c}(1) \\
\text { Maintenance time }\end{array}$ & $\begin{array}{c}(2) \\
\text { Total work time }\end{array}$ & $\begin{array}{c}\text { (3) } \\
\text { Leisure time }\end{array}$ \\
\hline & \multicolumn{3}{|c|}{ Panel A: Share of Husband's Time } \\
\hline $\begin{array}{l}\text { Asymmetric sex ratio } \\
\mathrm{M}: 20-49 / \mathrm{W}: 15-44\end{array}$ & $\begin{array}{l}-0.0020 \\
(-0.38) \\
\end{array}$ & $\begin{array}{c}0.0607 * * * \\
(4.72)\end{array}$ & $\begin{array}{c}-0.0387 * * * \\
(-3.19)\end{array}$ \\
\hline $\begin{array}{l}\text { Asymmetric sex ratio } \\
\mathrm{M}: 20-49 / \mathrm{W}: 15-44\end{array}$ & $\begin{array}{c}-0.0001 \\
(-0.03)\end{array}$ & $\begin{array}{c}\text { B: Share of Wife' } \\
-0.0446^{* * *} \\
(-3.61)\end{array}$ & $\begin{array}{l}0.0164 \\
(1.26) \\
\end{array}$ \\
\hline $\begin{array}{l}\text { Symmetric sex ratio } \\
\text { at age } 23\end{array}$ & $\begin{array}{l}0.0002 \\
(0.05) \\
\end{array}$ & $\begin{array}{c}\text { Share of Husban } \\
0.0545^{* * *} \\
(5.06)\end{array}$ & $\begin{array}{l}\text { me } \\
-0.0330 * * * \\
(-2.98)\end{array}$ \\
\hline $\begin{array}{l}\text { Symmetric sex ratio } \\
\text { at age } 23\end{array}$ & $\begin{array}{c}-0.0031 \\
(-0.83) \\
\end{array}$ & $\begin{array}{c}\text { D: Share of Wife' } \\
-0.0245^{*} \\
(-1.81) \\
\end{array}$ & $\begin{array}{l}0.0019 \\
(0.13) \\
\end{array}$ \\
\hline $\begin{array}{l}\text { Notes: Dependent vari } \\
\text { couple's time in each } \\
\text { county level when the } \\
\text { evaluated at county le } \\
\text { additionally control fo } \\
\text { the respondent was wo } \\
\text { was a weekend when t } \\
1990 \text { and } 1994 \text { and a f } \\
\text { statistics in parenthese } \\
10 \%, 5 \% \text { and } 1 \% \text { resp }\end{array}$ & $\begin{array}{l}\text { es are share of eithe } \\
\text { category. Sex rati } \\
\text { band was } 20 \text { years } \\
\text { when the husband } \\
\text { ssband's or wife's a } \\
\text { ng last week, if the } \\
\text { ime diary was take } \\
\text { set of county dumn } \\
\text { e clustered at coun } \\
\text { vely. }\end{array}$ & $\begin{array}{l}\text { sband's or wife' } \\
\text { r Panels A and } \\
\text { Sex ratios for P } \\
23 \text { years old. All } \\
\text { nd age squared, } \\
\text { ther was a non-r' } \\
\text { vo dummy variab } \\
\text { and } 10 \text {-year birth } \\
* * \text { and } * * * \text { indi }\end{array}$ & $\begin{array}{l}\text { to the sum of th } \\
\text { valuated at } \\
\text { and D are } \\
\text { sions } \\
\text { ny indicating if } \\
\text { ty and the day } \\
\text { licating year } \\
\text { t dummies. } t \\
\text { ignificant at }\end{array}$ \\
\hline
\end{tabular}




\section{Table 6. First Stage Estimation Results}

\begin{tabular}{lcc}
\hline & $\begin{array}{c}(1) \\
\text { Husband }\end{array}$ & $\begin{array}{c}(2) \\
\text { Wife }\end{array}$ \\
\cline { 2 - 3 } $\log$ Mainland Chinese men × cohort & $0.0082^{* * *}$ & $0.0088^{* * *}$ \\
1940-1949 & $(31.07)$ & $(33.95)$ \\
Observations & 18,134 & 18,134 \\
\hline Notes: Dependent variable is sex ratio when the husband was 20 years old. All \\
regressions additionally control for husband's or wife's age and age squared, a full set \\
of husband's or wife's education dummies, a dummy indicating if the respondent was \\
working last week, if the weather was a non-rainy day and the day was a weekend \\
when the time diary was taken, two dummy variables indicating year 1990 and 1994, \\
and a full set of county dummies and 10-year birth cohort dummies. $t$ statistics in \\
parentheses are clustered at county. *, ** and *** indicates significant at 10\%, 5\% \\
and 1\% respectively. Data source: Numbers of Mainland Chinese men are acquired \\
from the 1956 population census.
\end{tabular}


Table 7. 2SLS Estimates of Sex Ratio Effect on Time Shares

(1) (2)

Maintenance time Total work time Leisure time

Sex ratio

Panel A: Share of Husband's Time

\begin{tabular}{ccc}
\hline-0.0056 & $0.1020^{* *}$ & -0.0415 \\
$(-0.42)$ & $(1.96)$ & $(-0.88)$
\end{tabular}

Endogeneity test:

$p$-value

Sex ratio

\begin{tabular}{ccc}
0.5697 & 0.3622 & 0.9559 \\
\hline \multicolumn{3}{c}{ Panel B: Share of Wife’s Time } \\
\hline 0.0071 & $-0.1380^{* * *}$ & $0.0810^{* *}$ \\
$(0.64)$ & $(-4.0)$ & $(2.27)$
\end{tabular}

Endogeneity test:

0.0091

0.1121

Notes: dependent variables are ratios of either husband's or wife's time to the sum of the couple's time in each time category. Sex ratios are evaluated at county level when the husband was 20 years old. All regressions additionally control for husband's or wife's age and age squared, a full set of husband's or wife's education dummies, a dummy indicating if the respondent was working last week, if the weather was a nonrainy day and the day was a weekend when the time diary was taken, two dummy variables indicating year 1990 and 1994 and a full set of county dummies and 10-year birth cohort dummies. The instrumental variables are the interactions of the log of Mainland Chinese men and the two cohort dummies. $z$ statistics in parentheses are clustered at county. $*$, ** and *** indicates significant at $10 \%, 5 \%$ and $1 \%$ respectively. 
Editor, UWA Economics Discussion Papers:

Sam Hak Kan Tang

University of Western Australia

35 Sterling Hwy

Crawley WA 6009

Australia

Email: ecoadmin@biz.uwa.edu.au

The Economics Discussion Papers are available at:

1980 - 2002: http://ecompapers.biz.uwa.edu.au/paper/PDF\%20of\%20Discussion\%20Papers/

Since 2001: http://ideas.repec.org/s/uwa/wpaper1.html

Since 2004: $\quad$ http://www.business.uwa.edu.au/school/disciplines/economics

\begin{tabular}{|c|c|c|}
\hline \multicolumn{3}{|c|}{$\begin{array}{l}\text { ECONOMICS DISCUSSION PAPERS } \\
2015\end{array}$} \\
\hline $\begin{array}{l}\text { DP } \\
\text { NUMBER }\end{array}$ & AUTHORS & TITLE \\
\hline 15.01 & Robertson, P.E. and Robitaille, M.C. & $\begin{array}{l}\text { THE GRAVITY OF RESOURCES AND THE TYRANNY OF } \\
\text { DISTANCE }\end{array}$ \\
\hline 15.02 & Tyers, R. & $\begin{array}{l}\text { FINANCIAL INTEGRATION AND CHINA'S GLOBAL } \\
\text { IMPACT }\end{array}$ \\
\hline 15.03 & Clements, K.W. and Si, J. & $\begin{array}{l}\text { MORE ON THE PRICE-RESPONSIVENESS OF FOOD } \\
\text { CONSUMPTION }\end{array}$ \\
\hline 15.04 & Tang, S.H.K. & $\begin{array}{l}\text { PARENTS, MIGRANT DOMESTIC WORKERS, AND } \\
\text { CHILDREN'S SPEAKING OF A SECOND LANGUAGE: } \\
\text { EVIDENCE FROM HONG KONG }\end{array}$ \\
\hline 15.05 & Tyers, R. & $\begin{array}{l}\text { CHINA AND GLOBAL MACROECONOMIC } \\
\text { INTERDEPENDENCE }\end{array}$ \\
\hline 15.06 & $\begin{array}{l}\text { Fan, J., Wu, Y., Guo, X., Zhao, D. } \\
\text { and Marinova, D. }\end{array}$ & $\begin{array}{l}\text { REGIONAL DISPARITY OF EMBEDDED CARBON } \\
\text { FOOTPRINT AND ITS SOURCES IN CHINA: A } \\
\text { CONSUMPTION PERSPECTIVE }\end{array}$ \\
\hline 15.07 & $\begin{array}{l}\text { Fan, J., Wang, S., Wu, Y., Li, J. and } \\
\text { Zhao, D. }\end{array}$ & $\begin{array}{l}\text { BUFFER EFFECT AND PRICE EFFECT OF A PERSONAL } \\
\text { CARBON TRADING SCHEME }\end{array}$ \\
\hline 15.08 & Neill, K. & $\begin{array}{l}\text { WESTERN AUSTRALIA'S DOMESTIC GAS } \\
\text { RESERVATION POLICY THE ELEMENTAL ECONOMICS }\end{array}$ \\
\hline 15.09 & Collins, J., Baer, B. and Weber, E.J. & THE EVOLUTIONARY FOUNDATIONS OF ECONOMICS \\
\hline 15.10 & $\begin{array}{l}\text { Siddique, A., Selvanathan, E. A. and } \\
\text { Selvanathan, S. }\end{array}$ & $\begin{array}{l}\text { THE IMPACT OF EXTERNAL DEBT ON ECONOMIC } \\
\text { GROWTH: EMPIRICAL EVIDENCE FROM HIGHLY } \\
\text { INDEBTED POOR COUNTRIES }\end{array}$ \\
\hline 15.11 & Wu, Y. & $\begin{array}{l}\text { LOCAL GOVERNMENT DEBT AND ECONOMIC } \\
\text { GROWTH IN CHINA }\end{array}$ \\
\hline 15.12 & Tyers, R. and Bain, I. & $\begin{array}{l}\text { THE GLOBAL ECONOMIC IMPLICATIONS OF FREER } \\
\text { SKILLED MIGRATION }\end{array}$ \\
\hline 15.13 & Chen, A. and Groenewold, N. & $\begin{array}{l}\text { AN INCREASE IN THE RETIREMENT AGE IN CHINA: } \\
\text { THE REGIONAL ECONOMIC EFFECTS }\end{array}$ \\
\hline 15.14 & Knight, K. & PIGOU, A LOYAL MARSHALLIAN? \\
\hline
\end{tabular}




\begin{tabular}{|c|c|c|}
\hline 15.15 & Kristoffersen, I. & $\begin{array}{l}\text { THE AGE-HAPPINESS PUZZLE: THE ROLE OF } \\
\text { ECONOMIC CIRCUMSTANCES AND FINANCIAL } \\
\text { SATISFACTION }\end{array}$ \\
\hline 15.16 & Azwar, P. and Tyers, R. & INDONESIAN MACRO POLICY THROUGH TWO CRISES \\
\hline 15.17 & Asano, A. and Tyers, R. & $\begin{array}{l}\text { THIRD ARROW REFORMS AND JAPAN'S ECONOMIC } \\
\text { PERFORMANCE }\end{array}$ \\
\hline 15.18 & Arthmar, R. and McLure, M. & $\begin{array}{l}\text { ON BRITAIN'S RETURN TO THE GOLD STANDARD: } \\
\text { WAS THERE A 'PIGOU-MCKENNA SCHOOL’? }\end{array}$ \\
\hline 15.19 & $\begin{array}{l}\text { Fan, J., Li, Y., Wu, Y., Wang, S., } \\
\text { and Zhao, D. }\end{array}$ & $\begin{array}{l}\text { ALLOWANCE TRADING AND ENERGY CONSUMPTION } \\
\text { UNDER A PERSONAL CARBON TRADING SCHEME: A } \\
\text { DYNAMIC PROGRAMMING APPROACH }\end{array}$ \\
\hline 15.20 & Shehabi, M. & $\begin{array}{l}\text { AN EXTRAORDINARY RECOVERY: KUWAIT } \\
\text { FOLLOWING THE GULF WAR }\end{array}$ \\
\hline 15.21 & $\begin{array}{l}\text { Siddique, A., Sen, R., and } \\
\text { Srivastava, S. }\end{array}$ & $\begin{array}{l}\text { AUSTRALIA-THAILAND TRADE: AN ANALYSIS OF } \\
\text { COMPETITIVENESS AND THE EFFECTS OF THE } \\
\text { BILATERAL FTA }\end{array}$ \\
\hline 15.22 & Tyers, $\mathrm{R}$. & $\begin{array}{l}\text { SLOWER GROWTH AND VULNERABILITY TO } \\
\text { RECESSION: UPDATING CHINA'S GLOBAL IMPACT }\end{array}$ \\
\hline 15.23 & Arthmar, R. and McLure, M. & PIGOU ON WAR FINANCE AND STATE ACTION \\
\hline 15.24 & $\mathrm{Wu}, \mathrm{Y}$ & $\begin{array}{l}\text { CHINA'S CAPITAL STOCK SERIES BY REGION AND } \\
\text { SECTOR }\end{array}$ \\
\hline 15.25 & Clements, K. and Si, J. & $\begin{array}{l}\text { ENGEL'S LAW, DIET DIVERSITY AND THE QUALITY } \\
\text { OF FOOD CONSUMPTION }\end{array}$ \\
\hline 15.26 & Chen, S. & $\begin{array}{l}\text { SHIFTS OF DISTORTION AND CORRUPTION OVER } \\
\text { LOCAL POLITICAL CYCLES IN CHINA }\end{array}$ \\
\hline 15.27 & Chen, S. & $\begin{array}{l}\text { THE EFFECT OF A FISCAL SQUEEZE ON TAX } \\
\text { NFORCEMENT: EVIDENCE FROM A NATURAL } \\
\text { EXPERIMENT IN CHINA }\end{array}$ \\
\hline 15.28 & Jetter, M. & $\begin{array}{l}\text { BLOWING THINGS UP: THE EFFECT OF MEDIA } \\
\text { ATTENTION ON TERRORISM }\end{array}$ \\
\hline 15.29 & Tang, S. & $\begin{array}{l}\text { MEDIUM-TERM MACROECONOMIC VOLATILITY AND } \\
\text { ECONOMIC DEVELOPMENT: A NEW TECHNIQUE }\end{array}$ \\
\hline 15.30 & Alim, A., Hartley, P. and Lan, Y. & $\begin{array}{l}\text { ASIAN SPOT PRICES FOR LNG OTHER ENERGY } \\
\text { COMMODITIES }\end{array}$ \\
\hline 15.31 & $\begin{array}{l}\text { Gannon, B., Harris, D., Harris, M., } \\
\text { Magnusson, L., Hollingsworth, B., } \\
\text { Inder, B., Maitra, P, and Munford, L. }\end{array}$ & $\begin{array}{l}\text { NEW APPROACHES TO ESTIMATING THE CHILD } \\
\text { HEALTH-PARENTAL INCOME RELATIONSHIP }\end{array}$ \\
\hline 15.32 & Czaika, M. and Parsons, C. & $\begin{array}{l}\text { THE GRAVITY OF HIGH SKILLED MIGRATION } \\
\text { POLICIES }\end{array}$ \\
\hline 15.33 & $\begin{array}{l}\text { Parsons, C., Rojon, S., Samanani, F, } \\
\text { and Wettach, L. }\end{array}$ & $\begin{array}{l}\text { CONCEPTUALISING INTERNATIONAL HIGH-SKILLED } \\
\text { MIGRATION }\end{array}$ \\
\hline 15.34 & Chen, S. & $\begin{array}{l}\text { VAT RATE DISPERSION AND TFP LOSS IN CHINA'S } \\
\text { MANUFACTURING SECTOR }\end{array}$ \\
\hline 15.35 & $\begin{array}{l}\text { Tait, L., Siddique, A. and } \\
\text { Chatterjee, I. }\end{array}$ & $\begin{array}{l}\text { FOREIGN AID AND ECONOMIC GROWTH IN SUB- } \\
\text { SAHARAN AFRICA }\end{array}$ \\
\hline
\end{tabular}




\begin{tabular}{|c|c|c|}
\hline \multicolumn{3}{|c|}{$\begin{array}{l}\text { ECONOMICS DISCUSSION PAPERS } \\
2016\end{array}$} \\
\hline $\begin{array}{l}\text { DP } \\
\text { NUMBER }\end{array}$ & AUTHORS & TITLE \\
\hline 16.01 & Xu, R., Wu, Y. and Luan, J. & $\begin{array}{l}\text { ANALYSIS OF FARMERS' WILLINGNESS TO ADOPT } \\
\text { GENETICALLY MODIFIED INSECT-RESISTANT RICE IN } \\
\text { CHINA }\end{array}$ \\
\hline 16.02 & $\begin{array}{l}\text { Lia, Y., Fan, J., Zhao, D., Wu, Y. } \\
\text { and Li, J. }\end{array}$ & $\begin{array}{l}\text { TIERED GASOLINE PRICING: A PERSONAL CARBON } \\
\text { TRADING PERSPECTIVE }\end{array}$ \\
\hline 16.03 & Clements, K.W., Lan, Y. and Si, J. & UNCERTAINTY IN CURRENCY MISPRICING \\
\hline 16.04 & Parsons, C. and Vézina, P.L. & $\begin{array}{l}\text { MIGRANT NETWORKS AND TRADE:THE VIETNAMESE } \\
\text { BOAT PEOPLE AS A NATURAL EXPERIMENT }\end{array}$ \\
\hline 16.05 & Chang, S., Connelly, R. and Ma, P. & $\begin{array}{l}\text { WHAT WILL YOU DO IF I SAY 'I DO’?: THE EFFECT OF } \\
\text { THE SEX RATIO ON TIME USE WITHIN TAIWANESE } \\
\text { MARRIED COUPLES }\end{array}$ \\
\hline 16.06 & Yu, F. and Wu, Y. & $\begin{array}{l}\text { BIASES IN PATENT EXAMINATION AND FIRMS’ } \\
\text { RESPONSES: EVIDENCE FROM THE } \\
\text { PHARMACEUTICAL INDUSTRY }\end{array}$ \\
\hline 16.07 & $\begin{array}{l}\text { Fan, J., Li, J., Wu, Y., Wang, S. and } \\
\text { Zhao, D. }\end{array}$ & $\begin{array}{l}\text { THE EFFECTS OF ALLOWANCE PRICE ON ENERGY } \\
\text { DEMAND UNDER A PERSONAL CARBON TRADING } \\
\text { SCHEME }\end{array}$ \\
\hline 16.08 & Golley, J., Tyers, R. and Zhou, Y. & $\begin{array}{l}\text { CONTRACTIONS IN CHINESE FERTILITY AND } \\
\text { SAVINGS: LONG RUN DOMESTIC AND GLOBAL } \\
\text { IMPLICATIONS }\end{array}$ \\
\hline 16.09 & McGrath, G. and Neill, K. & $\begin{array}{l}\text { FOREIGN AND DOMESTIC OWNERSHIP IN WESTERN } \\
\text { AUSTRALIA'S GAS MARKET }\end{array}$ \\
\hline 16.10 & Clements, K.W. and Si, J. & SIMPLIFYING THE BIG MAC INDEX \\
\hline 16.11 & Priyati, R.Y. and Tyers, R. & $\begin{array}{l}\text { PRICE RELATIONSHIPS IN VEGETABLE OIL AND } \\
\text { ENERGY MARKETS }\end{array}$ \\
\hline 16.12 & Wu, J., Wu, Y. and Wang, B. & $\begin{array}{l}\text { THE GREENNESS OF CHINESE CITIES: CARBON } \\
\text { DIOXIDE EMISSION AND ITS DETERMINANTS }\end{array}$ \\
\hline 16.13 & $\begin{array}{l}\text { Arslan, C., Dumont, J.C., Kone, Z., } \\
\text { Özden, Ç., Parsons, C. and } \\
\text { Xenogiani, T. }\end{array}$ & $\begin{array}{l}\text { INTERNATIONAL MIGRATION TO THE OECD IN THE } \\
\text { TWENTY-FIRST CENTURY }\end{array}$ \\
\hline 16.14 & Tomioka, K. and Tyers, R. & $\begin{array}{l}\text { HAS FOREIGN GROWTH CONTRIBUTED TO } \\
\text { STAGNATION AND INEQUALITY IN JAPAN? }\end{array}$ \\
\hline 16.15 & Donovan, J. and Hartley, P. & $\begin{array}{l}\text { RIDING THE IRON ORE CYCLE: ACTIONS OF } \\
\text { AUSTRALIA'S MAJOR PRODUCERS }\end{array}$ \\
\hline
\end{tabular}

